\title{
Biolistic-mediated Transformation of Lilium longiflorum cv. Nellie White
}

\author{
Kathryn Kamo ${ }^{1}$
}

Floral and Nursery Plants Research Unit, USDA, 10300 Baltimore Avenue, Building 10A, Room 126, USDA National Arboretum, Beltsville, MD 20705-2350

\section{Bong Hee Han \\ Horticultural Research Institute, Rural Development Administration, Suwon, South Korea}

Additional index words. genetic engineering, gene gun, biolistics, regenerated plants, Easter lily

\begin{abstract}
Slow-growing compact calluses were initiated from bulb scales of Lilium longiflorum cv. Nellie White that had been cultured for at least 6 months on Murashige and Skoog (MS) medium with $9 \mu \mathrm{M}$ dicamba. To develop a reliable selection system, the sensitivity of nontransformed calluses and in vitro plants to different selective agents such as phosphinothricin, kanamycin, geneticin, paromomycin, and hygromycin was tested when grown on MS medium. Nontransformed calluses showed high sensitivity to $0.5 \mathrm{mg} \cdot \mathrm{L}^{-1}$ phosphinothricin, $25 \mathrm{mg} \cdot \mathrm{L}^{-1}$ geneticin, and $5 \mathrm{mg} \cdot \mathrm{L}^{-1}$ hygromycin. Nontransformed plants grown in vitro died on either $2 \mathrm{mg} \cdot \mathbf{L}^{-1}$ phosphinothricin or $75 \mathrm{mg} \cdot \mathbf{L}^{-1}$ hygromycin. Plants did not die when grown on either $200 \mathrm{mg} \cdot \mathrm{L}^{-1}$ kanamycin or 100 $\mathrm{mg} \cdot \mathrm{L}^{-1}$ geneticin, and $100 \mathrm{mg} \cdot \mathrm{L}^{-1}$ paromomycin stimulated plant growth. Transformation was achieved using biolistics on callus bombarded with either the bar-uidA fusion gene under control of the CaMV 35S promoter or $n p t$ II and uidA under control of the CaMV 35S promoter. One week after biolistic bombardment, callus bombarded with the bar-uidA fusion gene was cultured for 1 month on MS medium supplemented with $9 \mu \mathrm{M}$ dicamba and $0.1 \mathrm{mg} \cdot \mathrm{L}^{-1}$ phosphinothricin and then transferred to $0.2 \mathrm{mg} \cdot \mathrm{L}^{-1}$ phosphinothricin for 1 month followed by $1.0 \mathrm{mg} \cdot \mathrm{L}^{-1}$ for the next 4 months. Regenerating shoots and well-established plants were cultured on MS medium lacking hormones and with either $0.2 \mathrm{mg} \cdot \mathrm{L}^{-1}$ or $2.0 \mathrm{mg} \cdot \mathrm{L}^{-1}$ phosphinothricin, respectively. Callus bombarded with the $n p t$ II gene was cultured on MS medium with $50 \mathrm{mg} \cdot \mathrm{L}^{-1}$ geneticin until shoots regenerated. Regenerated shoots were cultured on MS medium lacking hormones. Under optimal conditions, 10 transgenic plants were selected from seven plates of callus bombarded with the bar-uidA fusion gene using phosphinothricin for selection. Both Southern hybridization of genomic DNA and polymerase chain reaction analysis verified the presence of the transgene in transformed 'Nellie White' plants. Transgenic plants were phenotypically normal, and they were crossed with nontransformed plants of $L$. longiflorum cvs. Sakai, Yin tung, Sakai, and Flavo. The presence of the bar gene in $41 \%$ of the T1 progeny plants confirmed stable integration of the transgene into the genomic DNA of transgenic lily plants. $\beta$-glucuronidase expression resulting from the uid $A$ gene was demonstrated in leaves and roots of some of the transgenic lily plants by histochemical staining, determination of the specific activity of the $\beta$-glucuronidase enzyme, and Northern hybridization.
\end{abstract}

Lilies are an important floral crop worldwide that ranked fourth for value on the Dutch Auction in 2002. They are used as cut flowers, pot plants, and grown in the garden. In the United States, all lily species sold as cut flowers had a wholesale value of

Received for publication 16 May 2008. Accepted for publication 27 June 2008 .

This project was funded in part by the Rural Development Administration of Korea and the Gloeckner Foundation.

Anne O'Connor is thanked for excellent assistance. Mention of a trademark, proprietary product, or vendor does not imply its approval to the exclusion of other products or vendors that may also be suitable.

${ }^{1}$ To whom reprint requests should be addressed; e-mail Kathryn.Kamo@ars.usda.gov sold, and pots of Easter lilies sold for a wholesale value of $\$ 38,488,000$ (USDA Statistics for Floriculture Crops, 2005).

There are a few recent reports on the transformation of lilies. Agrobacteriummediated transformation of Lilium longiflorum and Oriental lilies has been demonstrated (Hoshi et al., 2004; Mercuri et al., 2003; Ogaki et al., 2008). Biolistic-mediated transformation has been reported for $L$. longiflorum and Lilium $\times$ formolongi (Ahn et al., 2004; Cohen et al., 2004; Irifune et al., 2003; Watad et al., 1998).

All published transformation studies used the Easter lily, L. longiflorum, cv. Snow Queen as material (Cohen et al., 2004; Mercuri et al., 2003; Watad et al., 1998), except for Ahn et al. (2004) who used a hybrid of unknown origin. We have found that callus and plants of the L. longiflorum cv. Nellie White respond differently than 'Snow Queen' to auxins and kanamycin. Successful transformation of 'Snow Queen' was achieved using kanamycin for selection of putative transformants (Cohen et al., 2004), but our 'Nellie White' callus and plants cannot be selected using kanamycin because both grow on $200 \mathrm{mg} \cdot \mathrm{L}^{-1}$ kanamycin. Almost all of the Easter lilies currently grown in the United States are the cultivar Nellie White, and this has been the predominant cultivar in the United States for many years (Lee Riddle, Easter Lily Foundation, personal communication). Successful transformation in the United States requires a system for 'Nellie White' because Easter lilies in the United States are vegetatively propagated, and hybridizing 'Nellie White' with other cultivars is not a commercially feasible alternative at this time.

This is the first report for transformation of the L. longiflorum cv. Nellie White and the first verification that a transgene is transmitted to the T1 progeny of Lilium sp. indicating stable integration of the transgene.

\section{Materials and Methods}

In vitro plant materials. Bulb scales of Lilium longiflorum cv. Nellie White (bulbs received from Dahlstrom and Watts Bulbs, South River, CA) were surface-sterilized $20 \mathrm{~min}$ in $15 \%(\mathrm{v} / \mathrm{v})$ Clorox (Clorox Co., Oakland, CA) with 20 drops/L Tween 20
\$78.2 million making them the number one selling cut flower with $116,312,000$ stems

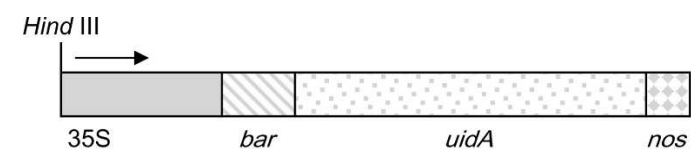

pDM327

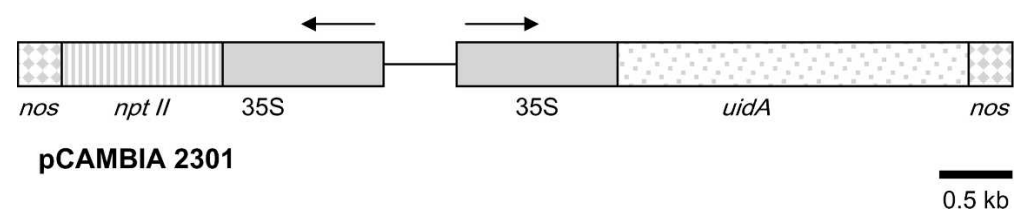

Fig. 1. Diagram of plasmid DNA constructs used for transformation experiments. pDM327 consists of the bar-uidA fusion gene under control of the CaMV 35S promoter, and pCAMBIA 2301 has the uidA and npt II genes under control of the CaMV $35 \mathrm{~S}$ promoters. 
followed by three rinses, $5 \mathrm{~min}$ each rinse, in sterile water. Sterile bulb scales were cultured on Murashige and Skoog (MS) medium (Murashige and Skoog, 1962) containing 3\% sucrose, $0.2 \%$ Phytagel (Sigma Aldrich Chemical Company, St. Louis), $26.7 \mu \mathrm{M}$ glycine, 0.29 $\mu \mathrm{M}$ thiamine, $4.1 \mu \mathrm{M}$ nicotinic acid, $2.4 \mu \mathrm{M}$ pyridoxine, 555.6 $\mu \mathrm{M}$ myo-inositol, $26.7 \mu \mathrm{M} 6-$ benzylaminopurine, and $0.54 \mu \mathrm{M} \alpha$-naphthaleneacetic acid. Plants that regenerated from the bulb scales were grown in vitro on MS medium lacking hormones. All media were adjusted to $\mathrm{pH} 5.8$ before autoclaving at $120 \mathrm{kPa}, 121^{\circ} \mathrm{C}$ for $20 \mathrm{~min}$. Plants were grown under cool-white fluorescent lights (40 to $60 \mu \mathrm{mol} \cdot \mathrm{m}^{-2} \cdot \mathrm{s}^{-1}$ ) with a 12-h photoperiod.

Callus was induced from bulb scales removed from in vitro-grown plants cultured on MS medium supplemented with $9 \mu \mathrm{M} 3,6$ dichloro-o-anisic acid (dicamba) in the dark at $25^{\circ} \mathrm{C}$. Plant and callus cultures were transferred once a month to fresh medium.

Evaluation of selection agents on growth of callus and plants. Approximately $1 \mathrm{~g}$ fresh weight of callus was grown on MS medium supplemented with $9 \mu \mathrm{M}$ dicamba. Kanamy$\operatorname{cin}\left(50,100,200 \mathrm{mg} \cdot \mathrm{L}^{-1}\right)$, paromomycin $(50$, $\left.75,100 \mathrm{mg} \cdot \mathrm{L}^{-1}\right)$, geneticin $(25,50,75,100$ $\left.\mathrm{mg} \cdot \mathrm{L}^{-1}\right)$, hygromycin $\left(1,5,10 \mathrm{mg} \cdot \mathrm{L}^{-1}\right)$, or phosphinothricin $\left(0.5,1.0,2.0 \mathrm{mg} \cdot \mathrm{L}^{-1}\right)$ was added to the medium by filter sterilization to the autoclaved medium. Callus was grown in the dark and transferred to fresh medium every 21 d. Four pieces of callus were cultured in separate petri plates on each concentration of the selection agent, and the final:initial fresh weight increase was determined for four to five transfer periods if the callus was growing well or three transfer periods if the callus died after one or two transfers onto fresh medium.

'Nellie White' shoots derived from bulb scales 2 to $3 \mathrm{~cm}$ tall were grown on MS medium supplemented with the selection agents as used for callus, except that the concentration of hygromycin was increased to 25,50 , and $75 \mathrm{mg} \cdot \mathrm{L}^{-1}$ because the lower concentrations used to inhibit callus growth did not inhibit growth of the plants. Shoots were grown in a 12 -h photoperiod and transferred every $21 \mathrm{~d}$ to fresh medium for five subcultures. Five shoots were grown on each concentration of the selection agent, and the experiment was repeated.

Transformation. Plasmid DNA was isolated using alkaline lysis followed by cesium chloride gradient purification (Maniatis et al., 1982). Callus was plated the day before bombardment on solid MS medium supplemented with $9 \mu \mathrm{M}$ dicamba and $0.125 \mathrm{~m}$ mannitol. The callus was bombarded with either pDM327 (received from David McElroy, Verdia, Redwood City, CA) that contains the bar-uidA fusion gene under control of the CaMV 35S promoter or pCAMBIA 2301 (CAMBIA, Canberra, Australia) that contains the $n p t I I$ and uidA genes under control of the CaMV 35S promoter (Fig. 1). Cells were bombarded $2 \times /$ plate using the PDS-/He system (Bio-Rad, Richmond, CA) that delivered $0.75 \mu \mathrm{m}$ gold particles. Gold particles were
Table 1. Number of putatively transformed lily plants resulting from five experiments ${ }^{\mathrm{z}}$.

\begin{tabular}{lcc}
\hline & Expt. 1: Callus was shot at one of two different pressures \\
\hline $\begin{array}{l}\text { No. of } \\
\text { plates }\end{array}$ & $\begin{array}{c}\text { Shooting pressure } \\
\text { (psi) }\end{array}$ & $\begin{array}{c}\text { No. of putatively } \\
\text { transformed plants }\end{array}$ \\
\hline 3 & 900 & 6 \\
4 & 1,100 & 4 \\
& Expt. 2: Callus was shot at one of three different pressures \\
\hline No. of & Shooting pressure & No. of putatively \\
plates & (psi) & transformed plants \\
\hline 6 & 900 & 2 \\
6 & 1,100 & 0 \\
6 & 1,300 & 0
\end{tabular}

Expt. 3: Callus was shot at either 900 or 1,100 psi and selected using either a step or nonstep selection with phosphinothricin

\begin{tabular}{lclc}
\hline $\begin{array}{l}\text { No. of } \\
\text { plates }\end{array}$ & $\begin{array}{c}\text { Pressure } \\
(\mathrm{psi})\end{array}$ & $\begin{array}{c}\text { Selection } \\
\text { type }\end{array}$ & $\begin{array}{c}\text { No. of putatively } \\
\text { transformed plants }\end{array}$ \\
\hline 4 & 900 & Step & 0 \\
4 & 1,100 & Nonstep & 1 \\
4 & 900 & Step & 1 \\
4 & 1,100 & Nonstep & 0
\end{tabular}

Expt. 4: Callus was shot at either 900 or 1,100 psi and at a distance of either 9 or $12 \mathrm{~cm}$ from the petri plate

\begin{tabular}{lccc}
\hline $\begin{array}{l}\text { No. of } \\
\text { plates }\end{array}$ & $\begin{array}{c}\text { Pressure } \\
(\mathrm{psi})\end{array}$ & $\begin{array}{c}\text { Distance } \\
(\mathrm{cm})\end{array}$ & $\begin{array}{r}\text { No. of putatively } \\
\text { transformed plants }\end{array}$ \\
\hline 3 & 900 & 9 & 0 \\
3 & 900 & 12 & 0 \\
3 & 1,100 & 9 & 0 \\
3 & 1,100 & 12 & 0
\end{tabular}

\begin{tabular}{lcc} 
& \multicolumn{2}{c}{ Expt. 5: Callus was selected using geneticin } \\
\hline $\begin{array}{l}\text { No. of } \\
\text { plates }\end{array}$ & $\begin{array}{c}\text { Pressure } \\
(\mathrm{psi})\end{array}$ & $\begin{array}{c}\text { No. of putatively } \\
\text { transformed plants }\end{array}$ \\
\hline 8 & 900 & 2
\end{tabular}

${ }^{z}$ Callus was transferred to increasing concentrations of phosphinothricin (step selection) unless stated otherwise. In one experiment, the selection agent was $50 \mathrm{mg} \cdot \mathrm{L}^{-1}$ geneticin, and a nonstep selection was used. Callus was bombarded with pDM327 or pCAMBIA 2301 in Expts. 1 through 4 and 5, respectively.
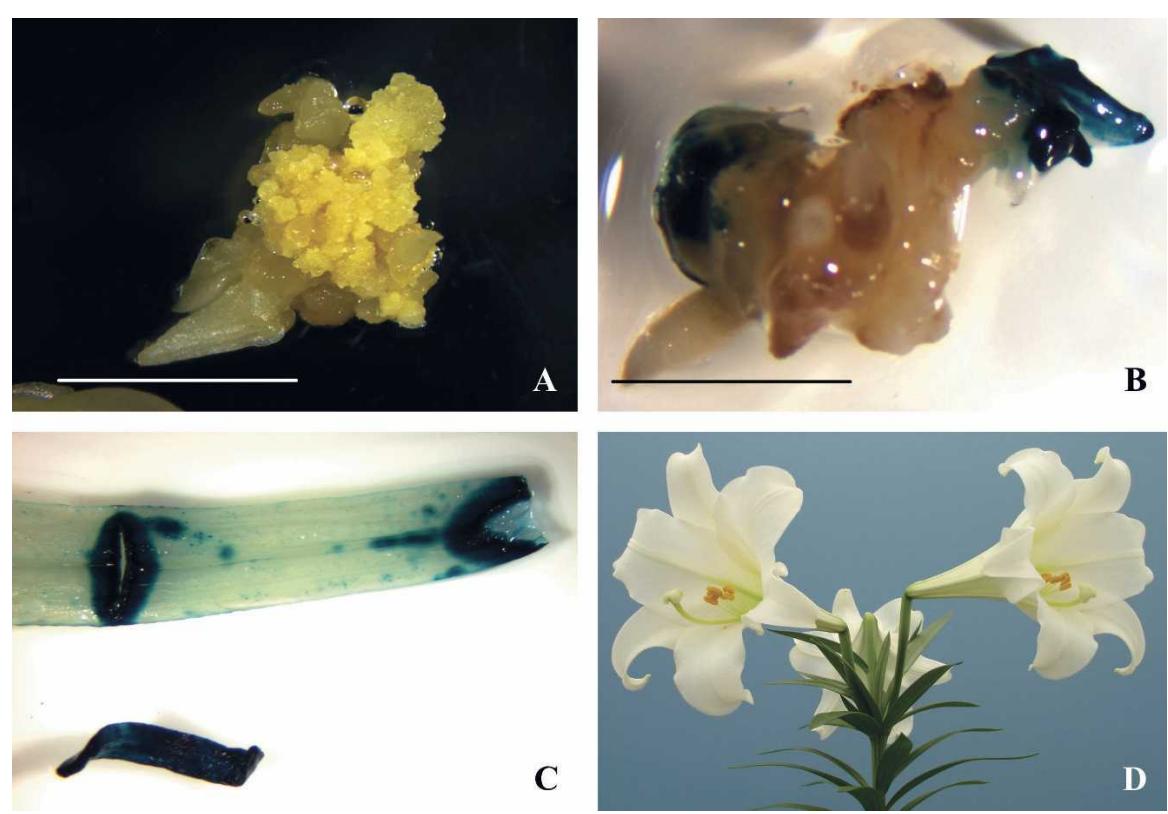

Fig. 2. (A) Callus growing on Murashige and Skoog medium supplemented with $9 \mu$ SMC dicamba and $3 \%$ sucrose. (B) Differentiation from callus showing $\beta$-glucuronidase (GUS) expression 2 months after bombarding. (C) Leaves from an in vitro-grown plant showing GUS expression after wounding (top) or throughout the leaf (bottom). (D) Transgenic plant that contains the bar-uidA fusion gene growing in the greenhouse. Bars represent $1 \mathrm{~cm}$. 

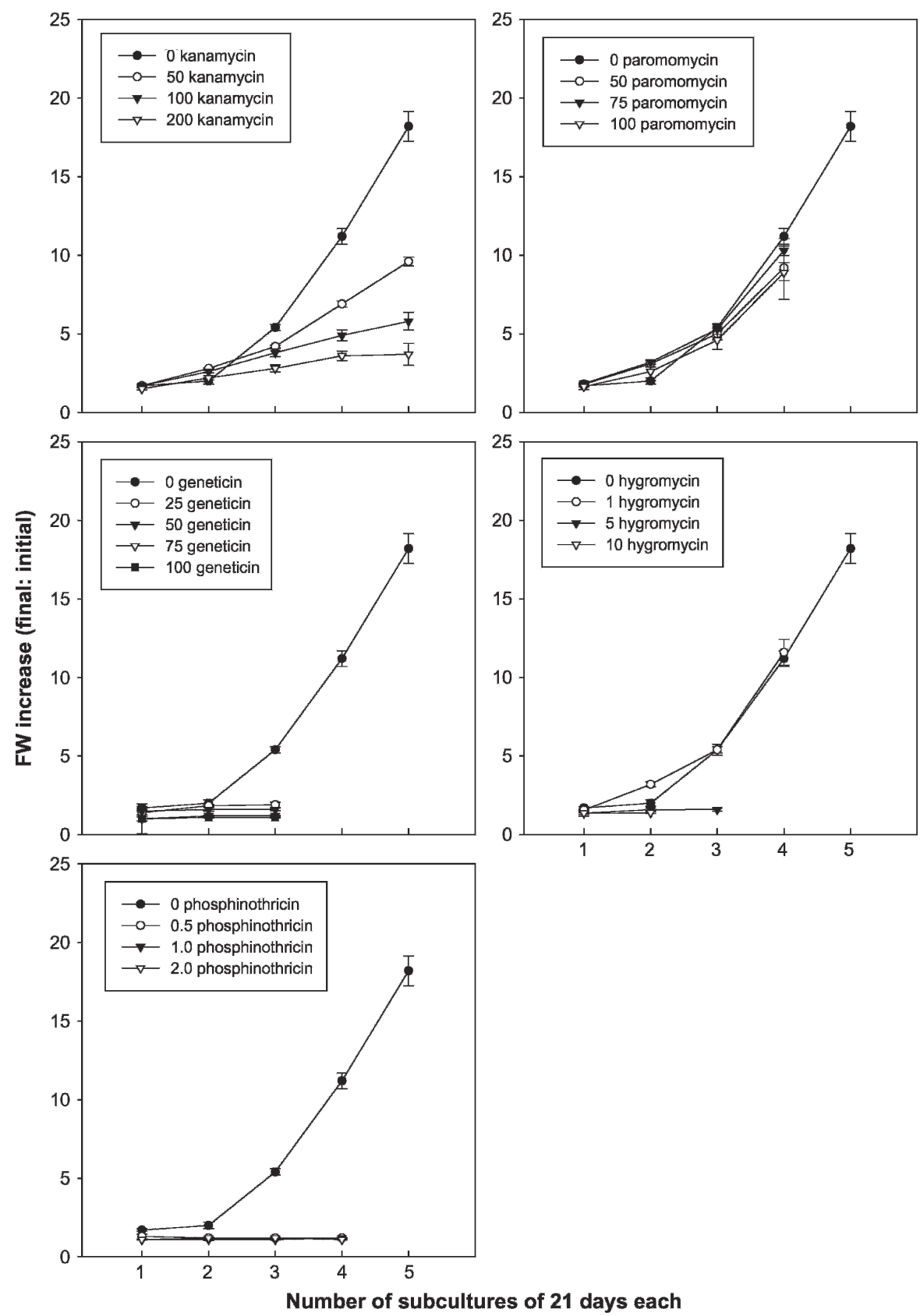

Fig. 3. Callus grown on Murashige and Skoog medium supplemented with various concentrations $\left(\mathrm{mg} \cdot \mathrm{L}^{-1}\right)$ of kanamycin, paromomycin, geneticin, hygromycin, or phosphinothricin was transferred every $21 \mathrm{~d}$ to fresh medium. Each data point is the mean of the fresh weight increase \pm SE for four pieces of callus.

coated with plasmid DNA according to the method of Sanford et al. (1993). The gene gun had a 1-cm gap and 1-cm flying membrane distance. The target distance was either 9 or $12 \mathrm{~cm}$, and cells were bombarded at 900 , 1100 , or 1300 psi.

Callus was transferred to selection medium $7 \mathrm{~d}$ after bombardment. A step selection was used for callus bombarded with pDM327 as follows. The selection medium was MS medium supplemented with $0.1 \mathrm{mg} \cdot \mathrm{L}^{-1}$ phosphinothricin (AgroEvo, Somerville, NJ) for 1 month, $0.2 \mathrm{mg} \cdot \mathrm{L}^{-1}$ the next month, and 1.0 $\mathrm{mg} \cdot \mathrm{L}^{-1}$ the following months. Any shoots that regenerated during this time were removed from the callus and transferred to MS medium lacking hormones and containing 0.2 $\mathrm{mg} \cdot \mathrm{L}^{-1}$ phosphinothricin. Callus was trans- ferred monthly to fresh medium and grown at $25^{\circ} \mathrm{C}$ in the dark. After $\approx 5$ months, when it became evident which callus had survived selection, the callus was transferred to MS medium lacking hormones and supplemented with $0.2 \mathrm{mg} \cdot \mathrm{L}^{-1}$ phosphinothricin. Callus was placed in a 12-h photoperiod when shoots began regenerating from the callus. Newly regenerated shoots were placed on MS medium with $0.2 \mathrm{mg} \cdot \mathrm{L}^{-1}$ phosphinothricin, and shoots that were $\approx 2 \mathrm{~cm}$ tall were transferred to Magenta jars containing MS medium and $2 \mathrm{mg} \cdot \mathrm{L}^{-1}$ phosphinothricin. Plants were transferred to fresh medium monthly and grown in a 12-h photoperiod provided by cool white fluorescent lights at an intensity of 40 to 60 $\mu \mathrm{mol} \cdot \mathrm{m}^{-2} \cdot \mathrm{s}^{-1}$ at $25{ }^{\circ} \mathrm{C}$ for regeneration and proliferation.
Five experiments were conducted to determine the factors that might affect the transformation efficiency of lily callus (Table $1)$. In two experiments, callus was bombarded with pDM327 using 900, 1100, or $1300 \mathrm{psi}$. A third experiment compared selection on phosphinothricin using either a step increase in phosphinothricin each month as described previously or an immediate exposure of the callus to MS medium with $9 \mu \mathrm{M}$ dicamba and $1.0 \mathrm{mg} \cdot \mathrm{L}^{-1}$ phosphinothricin 1 week after bombarding with pDM327. The target distance from the macrocarrier with gold to the petri plate with the callus, 9 or $12 \mathrm{~cm}$, was compared in a fourth experiment. Callus bombarded with pCAMBIA 2301 in Expt. 5 was cultured on MS medium with $9 \mu \mathrm{M}$ dicamba and $50 \mathrm{mg} \cdot \mathrm{L}^{-1}$ geneticin until shoots regenerated. Newly regenerated shoots larger than $2 \mathrm{~cm}$ tall were cultured on MS medium lacking hormones.

Transgenic plants that had developed several leaves and roots in vitro were transplanted to soil (Metromix 200; Scotts Company, Marysville, $\mathrm{OH}$ ), grown at $4{ }^{\circ} \mathrm{C}$ for 6 weeks for their roots to establish, and then grown in the greenhouse maintained at 24 to $26{ }^{\circ} \mathrm{C} / 21$ to $23{ }^{\circ} \mathrm{C}$ (day/night). Transgenic lilies cv. Nellie White was used as either the male or female parent in crosses with nontransformed L. longiflorum of cvs. Flavo, Snow Queen, Sakai, and Yin tung (gift from the Easter Lily Foundation). Seeds from light brown seed pods were cultured on MS medium for germination.

$\beta$-glucuronidase evaluation. The uidA gene codes for $\beta$-glucuronidase (GUS). Tissues of lilies were used for histochemical determination of GUS expression according to a modification of the method by Jefferson et al. (1987). Tissues were incubated for $16 \mathrm{~h}$ at $37{ }^{\circ} \mathrm{C}$ in a $0.1 \mathrm{M}$ sodium phosphate monobasic $\left(\mathrm{NaH}_{2} \mathrm{PO}_{4}\right)$, pH 7.0 solution containing $20 \%$ methanol, $0.1 \%$ Triton $\mathrm{X}$ $100,0.5 \mathrm{~mm}$ potassium ferricyanide, $0.5 \mathrm{~mm}$ potassium ferrocyanide, and $1 \mathrm{~mm}$ 5-bromo3 -chloro-3-indolyl- $\beta$-D-glucuronic acid that had been dissolved in a minimal amount of dimethyl sulfoxide. Leaves were destained by incubating for $48 \mathrm{~h}$ at $25{ }^{\circ} \mathrm{C}$ in $70 \%$ ethanol.

The specific activity of GUS was determined by fluorometric measurement of 4-methylumbelliferone according to the method by Jefferson et al. (1987). Three leaf samples, each $\approx 300 \mathrm{mg}$ fresh weight, were collected from each transgenic plant line grown in vitro and ground on ice in extraction buffer consisting of $50 \mathrm{~mm} \mathrm{NaH}_{2} \mathrm{PO}_{4}, \mathrm{pH} 7.0$, 10 mм EDTA, pH 8.0, 0.1\% Triton X-100, $0.1 \%$ sarkosyl, and $10 \mathrm{~mm} \beta$-mercaptoethanol using a microfuge tube and pestle. The ground tissues were centrifuged, and the supernatant was added to assay buffer (1 $\mathrm{mm}$ methyl umbelliferyl-D-glucuronide in extraction buffer) incubated at $37{ }^{\circ} \mathrm{C}$, and the reaction ended using $0.2 \mathrm{~m}$ sodium carbonate. Fluorescence was measured at 365 $\mathrm{nm}$ excitation and $455 \mathrm{~nm}$ emission using a BioRad VersaFluor Fluorometer (BioRad, Richmond, CA). The protein concentration of the plant extracts was calculated using the 

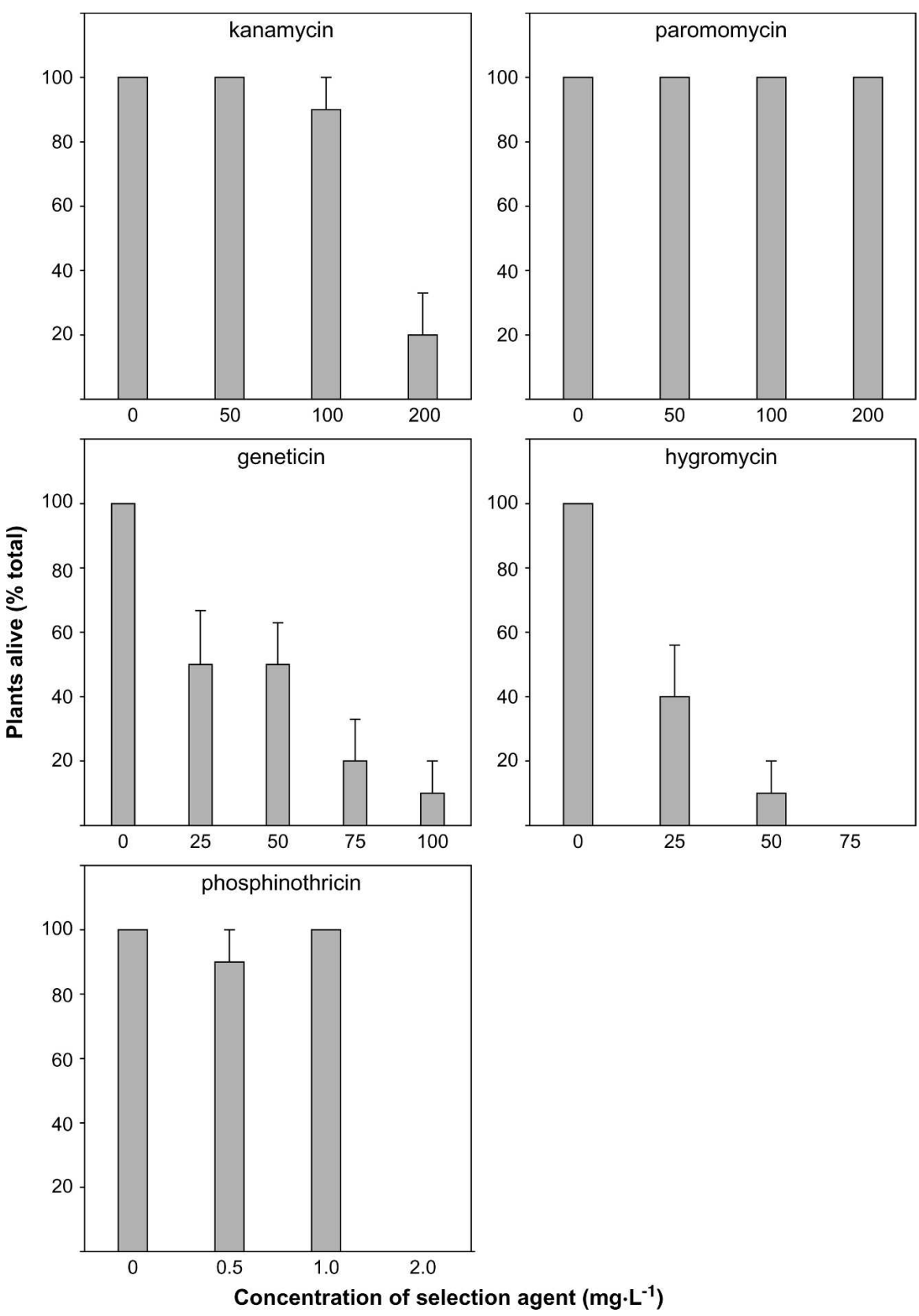

Fig. 4. 'Nellie White' shoots, 2 to $3 \mathrm{~cm}$ tall, were grown on Murashige and Skoog medium with various concentrations $\left(\mathrm{mg} \cdot \mathrm{L}^{-1}\right)$ of kanamycin, paromomycin, geneticin, hygromycin, or phosphinothricin. Plants were transferred to fresh medium every $21 \mathrm{~d}$ for six subcultures. Five plants were grown in separate Magenta jars on each concentration, and the experiment was repeated.

bicinchoninic protein assay reagent (Pierce Co., Rockford, IL) according to the manufacturer's instructions. Nontransformed plants were used as the negative control.

Genomic DNA analysis. DNA was isolated for polymerase chain reaction (PCR) from leaves of in vitro-grown plants using the FASTPREP plant DNA purification system according to the manufacturer's instructions (Qbiogene, Carlsbad, CA). The bar gene was amplified using the primers 5'-CAT GCC AGT TCC CGT GCT TGA AG-3' and 5'GTC AAC TTC CGT ACC GAG CCG CAG$3^{\prime}$. The uidA gene was amplified using the primers 5' -TAA CCT TCA CCC GGT TGC CAG AGG-3' and 5' -CTT TAA CTA TGC
CGG AAT CCA TCG-3'. Each PCR reaction consisted of $50 \mu \mathrm{L}$ containing $200 \mathrm{ng}$ DNA, $1.0 \mathrm{~mm} \mathrm{MgCl}_{2}, 0.2 \mathrm{~mm}$ of each dNTP, $0.2 \mu \mathrm{M}$ of each primer, and 0.5 units of Platinum Taq DNA polymerase (Invitrogen, Carlsbad, CA). Amplification for the bar and uidA genes was performed by denaturation at $94{ }^{\circ} \mathrm{C}$ for $4 \mathrm{~min}$ followed by 36 cycles of $94{ }^{\circ} \mathrm{C}$ for $20 \mathrm{~s}, 67^{\circ} \mathrm{C}$ for $30 \mathrm{~s}, 72^{\circ} \mathrm{C}$ for $2 \mathrm{~min}$, and then one cycle of $72^{\circ} \mathrm{C}$ for 10 min using an MJ Research PTC-0200 Peltier Themal Cycle (MJ Research, Waltham, MA).

DNA was isolated for Southern hybridization from leaves of in vitro-grown plants according to the method of Dellaporta et al. (1983). DNA $(30 \mu \mathrm{g})$ was digested with $\mathrm{Xba}$ I and then electrophoresed on a $0.7 \%$ agarose gel in TBE buffer ( $89 \mathrm{~mm}$ Tris, $89 \mathrm{~mm}$ boric acid, 2 mм EDTA, pH 8.0). Transfer of DNA to a Nytran nylon membrane (SchleicherSchuell, Keene, NH) was accomplished by capillary movement. The probe was a $2.4-\mathrm{kb}$ DNA fragment excised from pDM327 using Sst I, then gel-purified using Prepagene (BioRad) according to the manufacturer's instructions followed by labeling with $\alpha-\left[{ }^{32} \mathrm{P}\right] \mathrm{dCTP}$ using the DECAprime II kit (Ambion, Austin, TX). The DNA blot was incubated in prehybridization buffer for $1 \mathrm{~h}$ at $42{ }^{\circ} \mathrm{C}$ followed by incubation in hybridization buffer with the labeled probe for $16 \mathrm{~h}$ at $60{ }^{\circ} \mathrm{C}$ (Maniatis et al., 1982). The blot was washed for $15 \mathrm{~min}$ each wash at $55{ }^{\circ} \mathrm{C}$ in $2 \times \mathrm{SSC}$, $0.2 \%$ sodium dodecyl sulfate ( $\mathrm{SDS}$ ), then $1 \times$ SSC, $0.2 \%$ SDS, and lastly in $0.1 \times \mathrm{SSC}, 0.2 \%$ SDS. The blot was exposed to $\mathrm{x}$-ray film at $-70{ }^{\circ} \mathrm{C}$ with an intensifying screen for $5 \mathrm{~d}$.

Northern blot hybridization. RNA was isolated from leaves of in vitro-grown plants using lithium chloride (Vervoerd et al., 1989) and then subjected to electrophoresis using a MOPS/formaldehyde gel. RNA (10 $\mu \mathrm{g} /$ lane $)$ was transferred to a Nytran membrane using capillary movement. The RNA blot was incubated in Ultrahyb (Ambion) for $1 \mathrm{~h}$ at $42{ }^{\circ} \mathrm{C}$ followed by incubation in the same buffer with labeled probe for $16 \mathrm{~h}$ at $42{ }^{\circ} \mathrm{C}$. The probe was generated by PCR amplification of the $u i d A$ gene from pDM327 using the previously described primers. PCR amplification was performed using an MJ Research Microcycler PTC-200 programmed for $94{ }^{\circ} \mathrm{C}$ for $1 \mathrm{~min}$ followed by 30 cycles $\left(94{ }^{\circ} \mathrm{C}\right.$ for $1 \mathrm{~min}, 55^{\circ} \mathrm{C}$ for $1 \mathrm{~min}$, and $72{ }^{\circ} \mathrm{C}$ for $1 \mathrm{~min}$ ) followed by $72{ }^{\circ} \mathrm{C}$ for $10 \mathrm{~min}$. The PCR product was purified using the MinElute PCR Purification Kit (Qiagen, Valencia, CA) and then labeled with $\left[\alpha-{ }^{32} \mathrm{P}\right] \mathrm{dCTP}$ using the Decaprime Kit (Ambion). The RNA blot was washed at $42{ }^{\circ} \mathrm{C}$ for $15 \mathrm{~min}$ each wash in $2 \times \mathrm{SSC}, 0.2 \% \mathrm{SDS}$, then $1 \times \mathrm{SSC}, 0.2 \%$ SDS, and lastly $0.1 \times$ SSC, $0.2 \%$ SDS and then exposed to $\mathrm{x}$-ray film overnight with an intensifying screen at $-70{ }^{\circ} \mathrm{C}$.

Statistical analysis. The SE was determined for callus and shoot samples cultured on various concentrations of the selection agents, kanamycin, geneticin, paromomycin, hygromycin, and phosphinothricin. Four petri plates, each containing callus that weighed $\approx 1 \mathrm{~g}$ fresh weight, were cultured for each concentration of the selection agent. Each petri plate of callus was treated as a replicate. Five shoots were grown separately in a Magenta jar on each concentration of the selection agent, and the experiment was repeated. Each Magenta jar was treated as a replicate. The variation in specific activity of GUS between samples was determined by SE. Three leaf samples taken from plants grown in separate Magenta jars were analyzed for specific activity for each plant line.

\section{Results and Discussion}

Selectable marker agents. Callus induced from bulb scales of 'Nellie White' was hard 
and compact rather than soft and friable (Fig. 2A). It was determined that phosphinothricin $\left(0.5 \mathrm{mg} \cdot \mathrm{L}^{-1}\right)$, hygromycin $\left(5 \mathrm{mg} \cdot \mathrm{L}^{-1}\right)$, or geneticin $\left(50 \mathrm{mg} \cdot \mathrm{L}^{-1}\right)$ should be suitable for selecting putatively transformed callus because callus growth was effectively inhibited by these concentrations (Fig. 3).

All nontransformed shoots grown in vitro on MS medium with either phosphinothricin $\left(2 \mathrm{mg} \cdot \mathrm{L}^{-1}\right)$ or hygromycin $\left(75 \mathrm{mg} \cdot \mathrm{L}^{-1}\right)$ died after 6 months (Fig. 4). Most (90\%) of the nontransformed shoots died after 6 months of growth on geneticin $\left(100 \mathrm{mg} \cdot \mathrm{L}^{-1}\right)$ showing that the effective concentrations of selection agents are higher for lily plants than callus. Although others have successfully used 30 or $80 \mathrm{mg} \cdot \mathrm{L}^{-1}$ kanamycin for selection of putatively transformed lily shoots of the cv. Snow Queen (Cohen et al., 2004; Mercuri et al., 2003), 'Nellie White' shoots were not killed, and they did not turn white when grown on kanamycin $\left(200 \mathrm{mg} \cdot \mathrm{L}^{-1}\right)$. It is doubtful that a kanamycin concentration exceeding 200 $\mathrm{mg} \cdot \mathrm{L}^{-1}$ would be useful for selection of lily shoots, and a better alternative is using geneticin that 'Nellie White' shoots are sensitive to. Paromomycin (50 to 100 $\mathrm{mg} \cdot \mathrm{L}^{-1}$ ) stimulated growth of the 'Nellie White' shoots. Shoots grown on $100 \mathrm{mg} \cdot \mathrm{L}^{-1}$ paromomycin produced more leaves and roots than the control shoots and multiplied to form new shoots, whereas shoots growing on MS medium lacking paromomycin did not form any new shoots. Phosphinothricin and geneticin were chosen for selection of putatively transformed shoots in our experiments based on these results. Future experiments will use hygromycin because lily shoots were more sensitive to hygromycin than geneticin.

Transformation and transgene expression. Five experiments using various shooting pressures $(900,1100,1300 \mathrm{psi})$, two shooting distances $(9$ or $12 \mathrm{~cm})$, and either a step or nonstep selection were done for callus (Table 1). Selection was by a step selection using increasing concentrations of phosphinothricin in Expts. 1, 2, 3, and 4, except as indicated in Expt. 3. Although 10 putatively transformed plants were obtained from shooting seven plates of callus in Expt. 1, there were only zero to two putatively transformed plants from each of Expts. 2 through 5. Various shooting pressures, shooting distances, the step versus nonstep selection using phosphinothricin, and selection with geneticin did not appear to affect the transformation frequency. Other researchers have reported transformation resulting in only a few transformed lily plants except for Cohen et al. (2004) who obtained numerous transformants using a homemade, Finer-type gene gun. Molecular analysis is required to verify that these numerous transformants are independently transformed lines.

Putatively transformed plants were selected from callus that had been bombarded with pDM327 that consists of the bar-uidA fusion gene under control of the CaMV 35S promoter. Forty-eight hours after bombardment with pDM327, the callus showed numerous blue spots after histochemical
1A 4B NT 2A 40(1) P

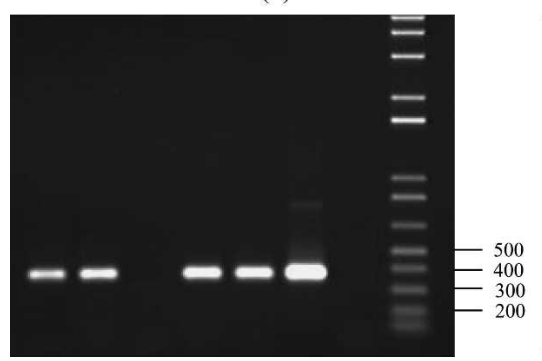

$\begin{array}{lllllll}1 \mathrm{~A} & 4 \mathrm{~B} & \mathrm{P} & \text { NT } & 2 \mathrm{~A} & 40(1) & \mathrm{P}\end{array}$

$\begin{array}{llllll}\text { NT } & 1 \mathrm{~A} & 4 \mathrm{~B} & 2 \mathrm{~A} & 40(1) & \mathrm{pDM} 327\end{array}$

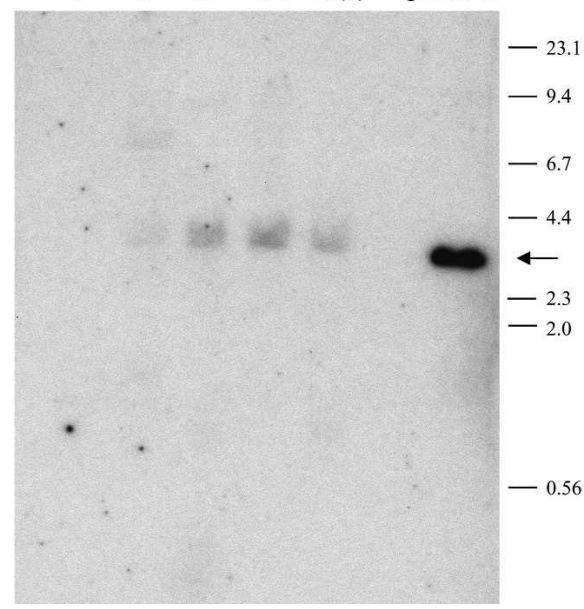

Fig. 5. (Top) DNA amplification of a portion of the bar (left) and uidA (right) genes. Four putatively transformed lily plant lines [2A, 40(1), 1A, 4B] shown to contain the bar gene and the uidA gene and a nontransformed plant (NT) were analyzed. Plasmid DNA (P) from pDM327 is amplified as a positive control. The 1-kb Plus DNA Ladder (Invitrogen) molecular weight markers are shown. (Bottom) Blot of genomic DNA isolated from lily and probed with the 2.4-kb bar-uidA fragment. Each lane contains $30 \mu \mathrm{g}$ of genomic DNA. Numbers represent the transformed plant lines, and NT DNA is shown. Arrow indicates the 2.9-kb bar-uidA-nos insert. Molecular weight markers are shown in kb.

staining for GUS expression. Histochemical staining of callus showed large regions, and the initial development of small plantlets with GUS expression 2 months after bombardment indicating sustained cell division of GUS-expressing cells (Fig. 2B). Transformed plants that regenerated from the callus showed GUS expression typically at wound sites of their leaves (Fig. 2C) and roots.

Both PCR analysis and Southern hybridization using DNA isolated from the leaves confirmed the presence of the bar and uidA genes in the genomic DNA (Fig. 5). Lines 1A, 2A, and 4B were selected from callus bombarded in separate petri plates in Expt. 1, and line 40(1) came from Expt. 3 when the callus was step-selected on phosphinothricin (Table 1).

Several leaf samples taken from a single plant were confirmed by PCR to contain the bar gene indicating that the plants analyzed were probably not chimeric (data now shown). The radioactive signal resulting from hybridization of transgene with the 2.4-kb bar-uidA probe was weak for line 1A but obvious for lines 4B, 2A, and 40(1) following Southern hybridization when the genomic DNA was incubated with $X b a$ I to release the bar-uidA gene insert. Although the baruidA gene insert should be the same size when isolated from lily genomic and plasmid pDM327 DNA, the pDM327 insert ran faster

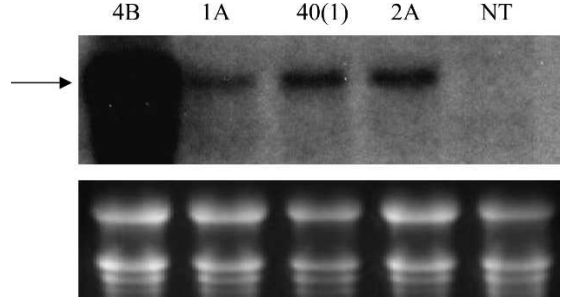

Fig. 6. (Top) Northern hybridization of an RNA blot showing an RNA transcript (arrow) for the uidA gene produced in leaves of four transformed plants $[2 \mathrm{~A}, 40(1), 1 \mathrm{~A}, 4 \mathrm{~B}]$ and none for a nontransformed plant (NT). (Bottom) Gel containing RNA stained with ethidium bromide to show amount of RNA loaded into each lane.

through the agarose gel than the genomic DNA insert, possibly as a result of a difference in DNA conformation.

Northern hybridization of an RNA blot demonstrated that all four transformants produced a 1.8-kb RNA transcript for the uidA gene (Fig. 6). Levels of the uidA transcript were considerably higher in line $4 \mathrm{~B}$ as compared with the other three lines. Possibly the site of insertion into the lily genome was more favorable for transgene expression in the case of line 4B than for the other three lines. GUS expression was visualized in all four lines by histochemical staining, and the 


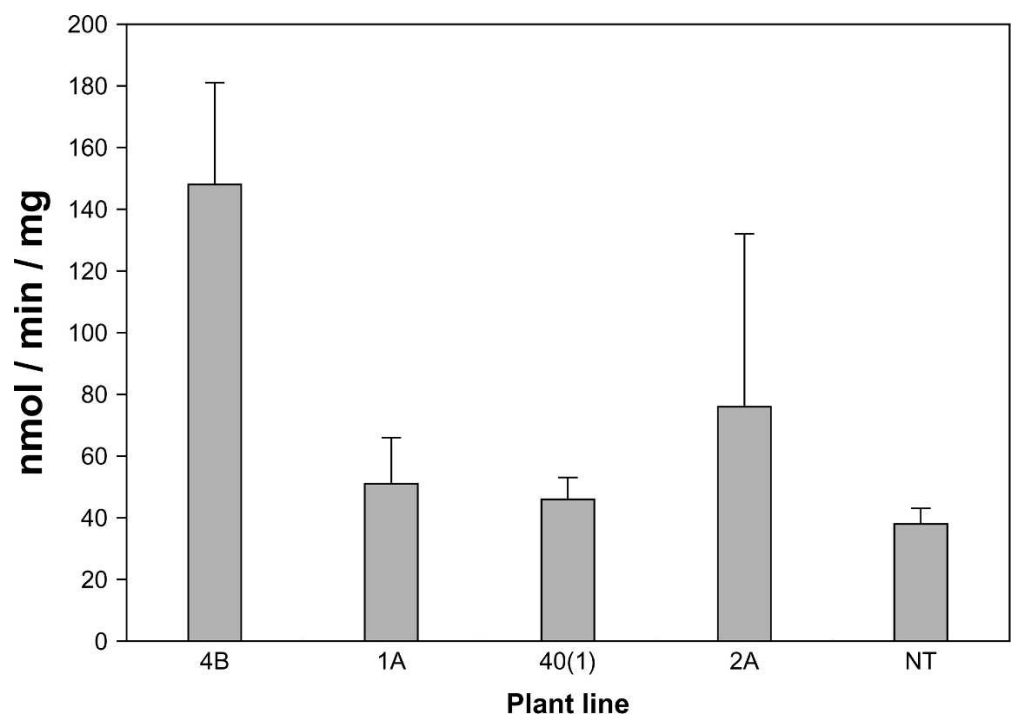

Fig. 7. Four transgenic lines vary in $\beta$-glucuronidase expression as determined by the specific activity of $\beta$-glucuronidase in leaves from plants grown in vitro. Three leaf samples were analyzed for each transgenic plant line.

specific activity of GUS was determined for leaves of each of the four plant lines analyzed (Fig. 7). The results by histochemical staining, specific activity of GUS, and Northern hybridization are in agreement that levels of GUS expression for line 4B are considerably higher than for lines $1 \mathrm{~A}, 2 \mathrm{~A}$, and 40(1).

Plants were grown in the greenhouse and developed phenotypically normal flowers as indicated by the numerous fertile seeds produced when the transgenic lilies were used as either the male or female parent in crosses with nontransformed L. longiflorum plants of cvs. Snow Queen, White Europe, Flavo, Yin tung, and Sakai (Fig. 2D). Approximately 100 to 200 seeds germinated from a single seed pod of Line $1 \mathrm{~A}$ when crossed with the cv. Flavo, and other crosses resulted in similar numbers of viable seeds. Twenty-seven $\mathrm{T} 1$ progeny plants resulting from the fertilization of 20 transgenic plants were analyzed by PCR (data not shown). The bar gene was present in $11(41 \%)$ of the T1 progeny plants indicating that the bar gene was stably integrated into the lily genome allowing it to be passed to the progeny. If a single copy of the transgene is integrated into the lily genome, $50 \%$ of the $\mathrm{T} 1$ progeny would have the transgene after crossing with a nontransformed plant. Because $41 \%$ of the $\mathrm{T} 1$ progeny had the transgene, it appears that the transgenic lines contained a single copy of the transgene. It was anticipated that very few or none of the $\mathrm{T} 1$ progeny would have the bar gene because the difficulty in transforming lilies made us hypothesize that possibly the lily genome rejects foreign DNA at a high frequency and that the transgene is often not stably integrated into its genome.

In conclusion, transformation of 'Nellie White' has been achieved resulting in fertile plants. Stable integration of the bar gene has been verified by successful transmission of the transgene to the T1 progeny. Expression of the uidA gene was demonstrated in leaves of transformed plant lines by both specific activity of GUS and presence of the RNA transcript. Future experiments are now needed to improve the transformation efficiency.

\section{Literature Cited}

Ahn, B.J., Y.H. Joung, and K.K. Kamo. 2004. Transgenic plants of Easter lily (Lilium longiflorum) with phosphinothricin resistance. J. Plant Biotech. 6:9-13.
Cohen, A., A. Lipsky, R. Arazi, A. Ion, R. Stav, D. Sandler-Ziv, C. Pintea, R. Barg, Y. Salts, S. Shabtai, V. Gaba, and A. Gera. 2004. Efficient genetic transformation of Lilium longiflorum and Ornithogalum dubium by particle acceleration followed by prolonged selection in liquid medium. Acta Hort. 651:131138.

Dellaporta, S., J. Wood, and J. Hicks. 1983. A plant DNA minipreparation: Version II. Plant Mol. Biol. Rep. 1:19-21.

Hoshi, Y., M. Kondo, S. Mori, Y. Adachi, M Nakano, and H. Kobayashi. 2004. Production of transgenic lily plants by Agrobacteriummediated transformation. Plant Cell Rep. 22: 359-364.

Irifune, K., Y. Morimoto, and M. Uchihama. 2003. Production of herbicide resistant transgenic lily plants by particle bombardment. J. Jpn. Soc. Hort. Sci. 72:511-516.

Jefferson, R.A., T.A. Kavanagh, and M.W. Bevan. 1987. GUS-fusions: $\beta$-glucuronidase as a sensitive and versatile gene fusion marker in higher plants. EMBO J. 6:3901-3907.

Maniatis, R., E.F. Fritsch, and J. Sambrook. 1982. Molecular cloning. A laboratory manual. Cold Spring Harbor Laboratory, New York, NY. p. 368-369.

Mercuri, A., L. De Benedetti, S. Bruna, R. Bregliano, C. Bianchini, G. Foglia, and T. Schiva. 2003. Agrobacterium-mediated transformation with rol genes of Lilium longiflorum Thunb. Acta Hort. 612:129-136.

Murashige, T. and F. Skoog. 1962. A revised medium for rapid assays with tobacco tissue cultures. Physiol. Plant. 15:473497.

Ogaki, M., Y. Furuichi, K. Kuroda, D.P. Chin, Y. Ogawa, and M. Mii. 2008. Importance of co-cultivation medium $\mathrm{pH}$ for successful Agrobacterium-mediated transformation of Lilium $\times$ formolongi. Plant Cell Rep. 27:699705.

Sanford, J.C., F.D. Smith, and J.A. Russell. 1993. Optimizing the biolistic process for different biological applications. Methods Enzymol. 217:483-510.

USDA Statistics for Floriculture Crops. (2005) $<$ http://usda.mannlib.cornell.edu/reports/nassr/ other/zfc-bb/>.

Vervoerd, T.C., B.M.M. Dekker, and A. Hoekema. 1989. A small- scale procedure for the rapid isolation of plant RNAs. Nucleic Acids Res. 17:2362.

Watad, A.A., D.J. Yun, T. Matsumoto, X. Niu, Y. Wu, A.K. Kononowicz, R.A. Bressan, and P.M. Hasegawa. 1998. Microprojectile bombardmentmediated transformation of Lilium longiflorum. Plant Cell Rep. 17:262-267. 